\title{
AVAILABILITY OF AGRICULTURAL LAND AND FULFILLMENT OF POPULATION FOOD NEEDS IN URBAN REGION (CASE STUDY OF PEKALONGAN CITY, CENTRAL JAVA, INDONESIA)
}

\author{
Imade Yoga Prasada*, Masyhuri \\ Program Studi Ekonomi Pertanian, Fakultas Pertanian Universitas Gadjah Mada, Indonesia \\ *corresponding author: imade.yogap@gmail.com
}

\begin{abstract}
The availability of agricultural land in urban areas has an important role in ensuring the availability of food for the population. The urban sprawl phenomenon that occurs in urban areas encourages the availability of agricultural land to experience shrinkage over time. Therefore, this study aims to determine the trend of the development of the area of agricultural land in Pekalongan City, and its impact on the fulfillment the food needs of the population. This study used a sample of urban areas in Pekalongan City using purposive sampling method and the data used are secondary data sourced from the Central Bureau of Statistics and the Food Security and Extension Agency (BKPP) in 1989 until 2017. The data used in this study are data agricultural land area, rice production, population, and consumption per capita of rice in Pekalongan City, as well as factor data for conversion of rice to rice. Furthermore, all data is processed and then analyzed using trend analysis. The results showed that the area of agricultural land in Pekalongan City is decreasing over time. Moreover, it followed by the quantity of rice offered that also have a downward trend. In addition, the demand trend of the population's rice also declined due to the decline of rice consumption per capita population in Pekalongan City during the period 1989 to 2017.
\end{abstract}

Keywords: Availability of agricultural land, supply, demand, rice, Pekalongan City

http://dx.doi.org/10.21776/ub.agrise.2020.020.1.5

Received 21 Juli 2019

Accepted 15 December 2019

Available online 31 January 2020

\section{INTRODUCTION}

Agricultural land is one of the most significant input for the production process in the agricultural sector. Without the availability of good agricultural land, the production process can be hampered or even impossible. The availability of agricultural land with good quality and quantity will assure the production process runs well too. Agricultural land is a key in the food production process, especially the staple food for Indonesian people, namely rice. Until now, the role of agricultural land as the main input in rice production activities has not been replaced or substituted with the use of technology that does not require large-scale of agricultural land such as hydroponic systems or vertical agriculture (verticulture). Therefore, food availability for the population will depend on the availability of agricultural land in a region.

The availability of agricultural land over the past few years has faced serious threats related to the conversion of very large agricultural land. The increasing shift in function of agricultural land can be seen in regions with rapid economic growth. Higher economic growth causes an increase in land demand from the non-agricultural sector (Yasar \& Siwar, 2016). This increased land demand from the non-agricultural sector can threaten the existence of agricultural land which basically has lower land rent than other economic sectors such as the commercial, industrial and trade sectors (Daulay, Eka Intan, 
Barus, \& Pramudya, 2016; Daulay, P, Barus, \& Bambang, 2016). The use of land with a low value of land rent will have the potential to shift functions to uses that have a higher rental value. In addition, the increase in population, and the high flow of urbanization also contributed to the conversion of agricultural land, especially agricultural land in the city area (Guneralp, Lwasa, Masundire, Parnell, \& Seto, 2017; Jiang \& Zhang, 2016). The Increasing the number of residents followed by an increase in the land need for settlements. The increment in land requirements from various non-agricultural sectors can only be fulfilled by changing land use from other uses that is the agricultural sector. This is due to the characteristic of natural resources in the form of land which has a relatively fixed area from time to time, so that the increase in land demand from an economic sector can only be fulfilled only if land use from other economic sectors decreases (Mahmood, Iftikhar, Saboor, Khan, \& Khan, 2016).

Urban areas are regions with a greater number of shifts in agricultural land compared to rural areas. This is because urban areas are often interpreted with high economic growth and a high population in the region compared to rural areas. The availability of agricultural land in urban areas are very important to note in the midst of high population growth in urban areas, the rapid economic growth of the nonagricultural sector, and the occurrence of conversion of agricultural land. The availability of agricultural land in urban areas will ensure the food production process for city residents can run well (Opitz, Berges, Piorr, \& Krikser, 2016). In addition, the availability of agricultural land in urban areas can guarantee the availability of food for the population of the city, so that the food security of the urban population can be maintained well in terms of the availability of food that can be produced by urban areas (Szabo, 2016).

Research in Karanganyar District, Central Java Province shows that a household will tend to have better access to food if the household does not convert agricultural land compared to households that do the conversion of agricultural land (Purwaningsih, Istiqomah, \& Sutomo, 2015). In addition, research held in the cities of Bandung and Yogyakarta show that urban areas are very vulnerable to the conversion of agricultural land into lands with strategic economic functions, namely settlements or housing, and real estate (Prihatin, 2015). The availability of agricultural land in the urban area and its impact on the ability of the urban area to meet the food needs of the population in the city area until now has not been well estimated, so that the needs and availability of food for the population in urban areas cannot be estimated. Therefore, this study will try to estimate the availability of agricultural land in urban areas and connect it to the availability of rice and fulfillment of rice needs for people in urban areas.

\section{RESEARCH METHODS}

This research was carried out using secondary data sourced from the Central Statistics Agency of Pekalongan City and the Republic of Indonesia Food Security and Extension Agency. Pekalongan City was chosen as the location of the study determined by using a purposive sampling method on the grounds that Pekalongan City is a city on Java Island which has a large percentage of agricultural land area compared to other cities. The data used in this study were data on wetland area, rice production, population, and per capita rice consumption of the population in Pekalongan City, as well as factor data on conversion of rice to rice. The data period used is 1989 to 2017. Furthermore, the data can be analysed by using the following methods.

\section{Availability of Agricultural Land and Fulfilment of Rice Needs}

Availability of agricultural land and fulfilment of rice needs can be analyzed using the trend analysis method. Trend analysis is carried out to provide information regarding the rising or falling trend of agricultural land in the long run. Trend analysis requires quite long data, the longer the data used for trend analysis, the better and more interpretive analysis results will be obtained (Veno \& Syamsudin, 2016). Trend analysis can be done by applying the equation model as follows:

$$
\mathrm{Y}=\mathrm{a}+\mathrm{bX}
$$

Information:

$\mathrm{Y}=$ Dependent variable (not free) whose trend is sought, namely the area of agricultural land (hectares)

$\mathrm{X}=$ Independent variable (free) using time (year) 
Rice Production Data Conversion into Rice Production Data

Rice production data available in the publication of the Central Statistics Agency was rice production data in the form of paddy, so the data needs to be converted into rice first. Production data that has been converted into rice can then be used to see a comparison between rice demand and supply. The process of converting paddy to rice production can be done using the following formula (BKPP, 2017).

Food Availability $=$ Gross paddy production Paddy conversion factor

Gross rice production (tons) was rice production sourced from the Central Statistics Agency of Pekalongan City and rice conversion factors were the numbers used to adjust or equalize paddy production into rice production. The conversion factor consists of several parts, namely the conversion factor of gross paddy into available paddy, and the conversion factor of paddy to rice, as well as the factor of gross rice conversion into rice available (BKPP, 2017). The conversion factor for gross paddy into paddy available, namely the need for seeds $(0.90 \%)$, paddy for feed $(0.44 \%)$, scattered paddy $(5.40 \%)$, and paddy for the non-food industry $(0.56 \%)$. Furthermore, the conversion factor of paddy to gross rice is $63.20 \%$. After the gross rice production data was obtained, the production of net rice can be calculated by using the gross rice conversion factor into net rice, namely rice for feed $(0.17 \%)$, scattered rice $(2.50 \%)$, and rice for the nonfood industry $(0.66 \%)$.

\section{Population Rice Consumption Needs}

The need for rice consumption by residents in Pekalongan City can be calculated using the formula:

$$
\begin{gathered}
\text { Food needs }=\text { Rice consumption per capita } \mathrm{x} \\
\text { population }
\end{gathered}
$$

The total food (rice) needs of the population in Pekalongan City reflect the amount of rice demand that needs to be fulfilled. The need for rice which is not balanced with the supply of rice indicates a food surplus or deficit in urban areas. The food surplus can occur when rice supply in Pekalongan City is higher than the demand for rice which must be fulfilled, whereas the food deficit can occur when the supply of rice is lower than the amount of rice demand that must be fulfilled.

\section{RESULTS AND DISCUSSION}

\section{Trends in Availability of Agricultural Land in Pekalongan City}

The area of agricultural land in Pekalongan City tends to decrease over time. This can be seen from data sourced from the Central Bureau of Statistics from 1989 to 2017 which is declining (BPS, 2018). Agricultural land has a very important role in meeting the food needs of city residents. Agricultural land with sufficient quantity and quality can support food production and meet the food needs of the community. Conversely, agricultural land with relatively low quantity and quality can hamper the food production process. The trend in the development of agricultural land in Pekalongan City in the period 1989 to 2017 can be seen in figure 1 below.

Based on figure 1, visually it can be seen the trend of agricultural land area in Pekalongan City tends to decrease from year to year in the period 1989 to 2017. The results of these trends can be written in the following equations:

$$
\mathrm{Y}=1830.5-25.56 \mathrm{X}
$$

In this equation, the regression coefficient sign is negative, so this shows the existence of an opposite direction relationship between the dependent variable of wetland area in Pekalongan City with the dependent variable time (year). The regression coefficient of -25.56 reflects that if there is an addition of one unit per year, it can cause a decrease of agricultural land by 25.56 hectares. Agricultural land which is declining in the Pekalongan City area can occur because of the large conversion of agricultural land in Pekalongan City.

Based on data from the Central Statistics Agency, in the period 1989 to 2017, there has been a conversion of 775 hectares of agricultural land or decreased by $44.16 \%$ (BPS, 2018). The results of this analysis are in line with research in the Special Region of Yogyakarta which experienced massive conversion of agricultural land. Agricultural land in the Special Region of Yogyakarta is recorded as having changed the function of agricultural land by 3,089 hectares over the past 10 years (Prasada \& Rosa, 2018).

Conversion of agricultural land in Pekalongan City area can be caused by the occurrence of urban sprawl or expansion of urban areas to suburban areas, so that agricultural land located in suburban areas converted to non-agricultural sectors. The occurrence of urban sprawl is triggered by an increase in economic activity in the city center so 
that land needs are increasing and there is an increase in population in urban areas (Al-Kofahi, Hammouri, Sawalhah, Al-Hammouri, \& Aukour, 2018). The phenomenon of urban sprawl which causes the conversion of agricultural land basically can be prevented and controlled as long as the policy of determining the Spatial and Regional Plan (RTRW) in urban areas can be implemented properly, so that the existence of agricultural land in the city can be maintained.

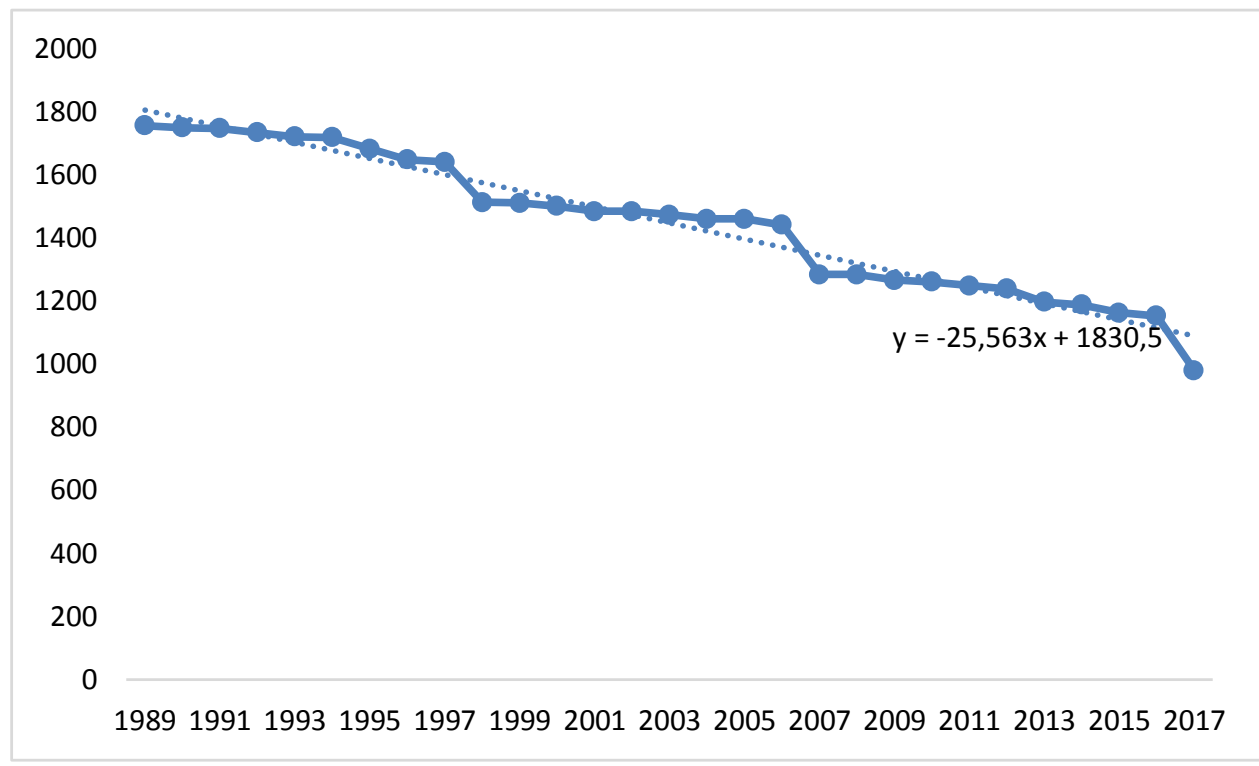

Figure 1. Trend of Agricultural Land Area in Pekalongan City

Rice Supply Trends in Pekalongan City

The supply of rice is calculated using data on rice production in Pekalongan City provided by the Central Bureau of Statistics in the period 1989 to 2017. The production data is then adjusted or equalized by using the conversion factor of gross rice into available rice provided by the Food Security Agency and Extension of the Republic of Indonesia. The supply trend of rice in Pekalongan City can be seen in figure 2 below.

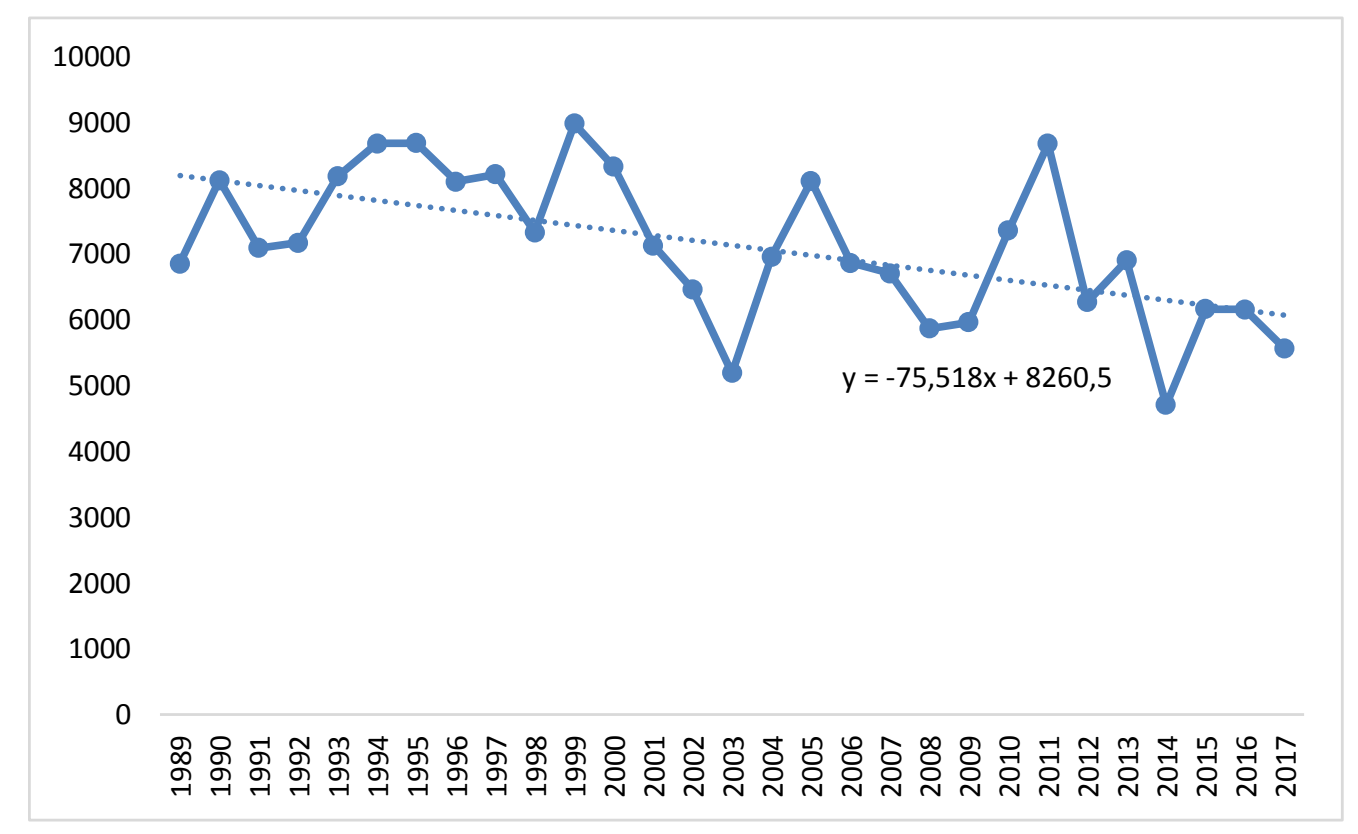

Figure 2. Trend of Rice Offerings in Pekalongan City 
Based on figure 2, it can be seen that visually, the supply of rice in Pekalongan City is experiencing a trend that has been decreasing since the period of 1989 until the period of 2017. The results of the trend in Figure 2 can be written in the equation as follows:

$$
\mathrm{Y}=8260.5-75.52 \mathrm{x}
$$

From the above equation, it can be seen that the regression coefficient has a negative sign, so this shows the existence of an opposite relationship between the variable supply of rice in Pekalongan City with a variable time (year). The regression coefficient of -75.52 shows that every time (year) variable increase of one unit will cause a decrease in rice supply by 75.52 tons.

The tendency of decreasing supply of rice in Pekalongan City can be caused by the amount of agricultural land in Pekalongan City which is shrinking due to the conversion of agricultural land. This has an impact on the reduced amount of land that can be planted with food crops, so it also contributes to the decline in rice production that can be produced. Rice supply can be increased by seeking marginal land use in urban areas for food crop farming activities or by applying new technologies to increase the productivity of agricultural land. In addition, improvements to irrigation networks, and increased incentives for farmers in the form of increasing grain prices can boost the supply of rice (Prasada, Dhamira, \& Nugroho, 2018).

\section{Trend of Rice Demand in Pekalongan City}

The demand for rice in Pekalongan City can be calculated by multiplying rice consumption per capita population in Pekalongan City with the population in Pekalongan City in a certain period. Based on this formula, it can be seen that the magnitude of the demand for rice will depend on the level of rice consumption per capita population and the high population size. The trend in demand for rice in Pekalongan City can be seen in figure 3 below.

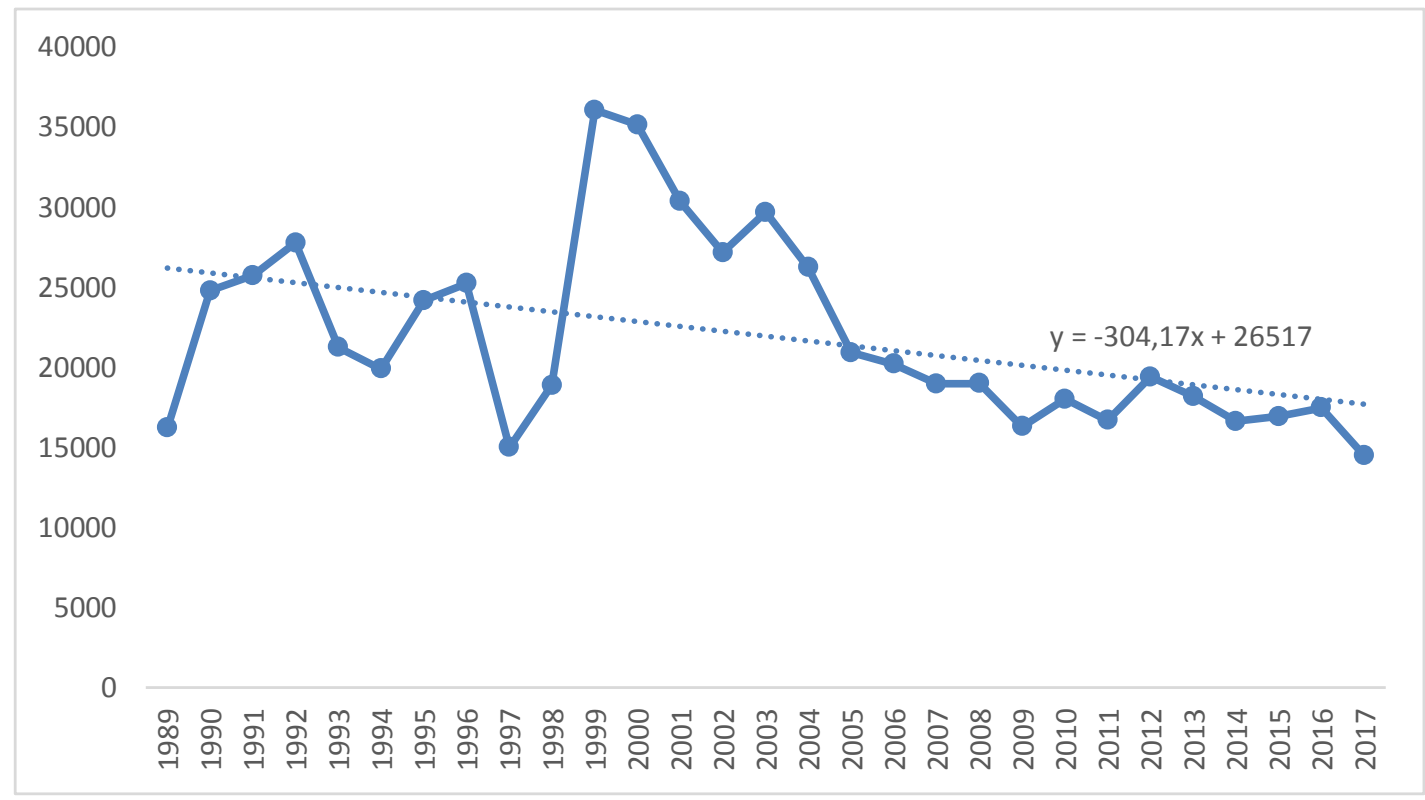

Figure 3. Trend of Demand for Rice in Pekalongan City

Based on Figure 3, it can be seen that visually the trend of demand for rice in Pekalongan City tends to decline from year to year in the period 1989 to 2017. The trend of demand for rice in Pekalongan City can be written in the following equation.

$$
\mathrm{Y}=26,517-304,171 \mathrm{X}
$$

From the equation above it can be seen that the regression coefficient of demand for rice in the population of Pekalongan City has a negative sign, thus it gives an illustration that there is an opposite relationship between the rice demand variable and the time (year) variable. The regression coefficient value is $-304,171$ which means that there is an increase in the variable time (year) of one unit which can cause a decrease in large demand of 304,171 tons. The demand for rice in Pekalongan City tends 
to decrease due to a decrease in rice consumption per capita population in Pekalongan City.

Based on data from the Central Statistics Agency of Pekalongan City, in the period 19892003 the consumption of rice per capita population in Pekalongan City averaged 103.31 kilograms per capita per year. The value of rice consumption is much smaller compared to the period 2004-2017 with the average rice consumption per capita amounting to 65.64 kilograms per capita per year (BPS, 2018). The decline in rice consumption per capita population in Pekalongan City can be caused by food diversification carried out by the population in Pekalongan City, so that staple food no longer depends entirely on rice consumption. Food diversification allows a shift in the consumption of staple food for the population, which originally relies entirely on rice consumption and can be turned into consumption of other food substitutes for rice (Rahmadanih, Bulkis, Amrullah, Rukka, \& Arsyad, 2015; Wicaksono, Putra, \& Muhartini, 2015).

\section{Rice Surplus/Deficit in Pekalongan City}

Based on the offer data and data on demand for rice from the population in Pekalongan City, it can be seen that during the period of 1989 to 2017 the population of Pekalongan City experienced a rice deficit. This can be seen from the amount of rice demand which is far greater than the rice supply that occurs in Pekalongan City. The rice deficit of the population in Pekalongan City has the consequence of ensuring the availability of food for the population, so rice needs to be provided not only from rice production within the Pekalongan City area, but also must be fulfilled by taking rice from other regions.

Provision of rice from outside the Pekalongan City area shows the dependence of Pekalongan City on rice production produced from the area around Pekalongan City, namely Batang Regency and Pekalongan Regency. The trend of the large rice deficit in Pekalongan City during the period 1989 to 2017 can be seen in the following Figure 4.

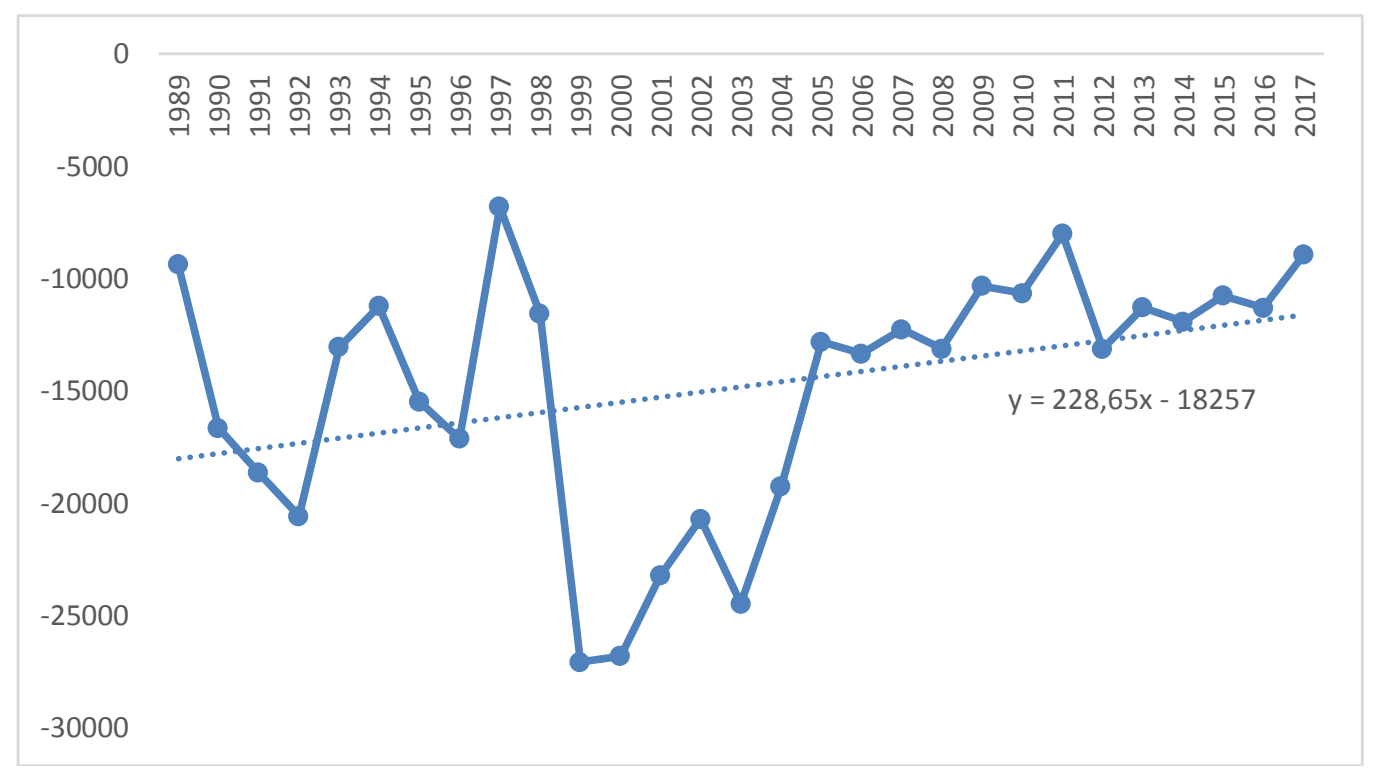

Figure 3. Trend of Rice Deficit in Pekalongan City

In the period of 1989 to 2017 based on the results of calculations using data from the Central Statistics Agency of Pekalongan City, it was shown that the average rice deficit reached 14,827 tons per year (BPS, 2018). However, if we pay attention to the deficit trend of rice in Pekalongan City, it can be seen that the trend of rice deficit tends to decline from year to year from the period 1989 to 2017 . The deficit trend of rice in Pekalongan City can be written in the equation as follows.

$$
Y=18.257+228.65 x
$$

Based on the above equation it can be seen that the deficit trend of rice in Pekalongan City has a sign on the regression coefficient which is positive. This 
illustrates that the rice deficit in Pekalongan City has a tendency to decline from year to year. The tendency of a decrease in rice deficit can occur because of the smaller demand for rice in Pekalongan City due to a decrease in rice consumption per capita population in Pekalongan City.

\section{CONCLUSION}

The availability of agricultural land in urban areas has a very important role in providing food for the population in Pekalongan City. Without the availability of agricultural land with good quantity and quality, the process of food production can be hampered and consequently the smaller production of food that can be produced in the region and the impact of the emergence of food dependence on urban areas to other surrounding areas. This dependence will occur when the urban area is unable to meet the food needs of its population independently, in this case the demand for food for the population is far greater than the supply of food from the production activities carried out. Availability of agricultural land in urban areas faces serious challenges related to the conversion of agricultural land. However, this can be minimized by implementing the best Spatial and Regional Plan (RTRW) regulations.

\section{ACKNOWLEDGEMNT}

Thank you, the authors convey to the Education Fund Management Institute (LPDP) for their assistance, both financially and non-financially so that the authors can publish the results of research related to the availability of agricultural land and fulfillment of the food needs of the population in urban areas.

\section{REFERENCES}

Al-Kofahi, S. D., Hammouri, N., Sawalhah, M. N., Al-Hammouri, A. A., \& Aukour, F. J. (2018). Assessment of the urban sprawl on agriculture lands of two major municipalities in Jordan using supervised classification techniques. Arabian Journal of Geosciences, 11(3), 11-45. https://doi.org/10.1007/s12517-018-3398-5

BKPP. (2017). Neraca Bahan Makanan (NBM). Jakarta: Badan Ketahanan Pangan dan Penyuluhan Republik Indonesia.
BPS. (2018). Kota Pekalongan Dalam Angka. Kota Pekalongan, Jawa Tengah: Badan Pusat Statistik Kota Pekalongan.

Daulay, A. R., Eka Intan, K. P., Barus, B., \& Pramudya, N. B. (2016). Rice land conversion into plantation crop and challenges on sustainable land use system in the East Tanjung Jabung Regency. Procedia - Social and Behavioral Sciences, 227(2016), 174 180.

https://doi.org/10.1016/j.sbspro.2016.06.059

Daulay, A. R., P, E. I. K., Barus, B., \& Bambang, P. N. (2016). The Acceptable Incentive Value To Succeed Paddy Land Protection Program in Regency of East Tanjung Jabung, Indonesia. ARPN Journal of Agricultural And Biological Science, 11(8), 307-312.

Guneralp, B., Lwasa, S., Masundire, H., Parnell, S., \& Seto, K. C. (2017). Urbanization in Africa : challenges and opportunities for conservation. Environmental Reearch Letters, 13(2018), 19.

Jiang, L., \& Zhang, Y. (2016). Modeling Urban Expansion and Agricultural Land Conversion in Henan Province, China: An Integration of Land Use and Socioeconomic Data. Sustainability, $\quad 8(9), \quad 920$. https://doi.org/10.3390/su8090920

Mahmood, Z., Iftikhar, S., Saboor, A., Khan, A. U., \& Khan, M. (2016). Agriculture land resources and food security nexus in Punjab, Pakistan: an empirical ascertainment. Food and Agricultural Immunology, 27(1), 52-71. https://doi.org/10.1080/09540105.2015.10795 93

Opitz, I., Berges, R., Piorr, A., \& Krikser, T. (2016). Contributing to food security in urban areas: differences between urban agriculture and peri-urban agriculture in the Global North. Agriculture and Human Values, 33(2), 341358. https://doi.org/10.1007/s10460-0159610-2

Prasada, I. M. Y., Dhamira, A., \& Nugroho, A. D. (2018). Supply Response of Paddy in East Java: Policy Implications to Increase Rice. AGRARIS: Journal of Agribusiness and Rural Development Research, 4(2), 129-138. 
Prasada, I. M. Y., \& Rosa, T. A. (2018). Dampak alih fungsi lahan sawah terhadap ketahanan pangan di Daerah Istimewa Yogyakarta. Jurnal Sosial Ekonomi Pertanian, 14(1), 180194.

Prihatin, R. B. (2015). Alih Fungsi Lahan di Perkotaan (Studi Kasus di Kota Bandung dan Yogyakarta). Jurnal Aspirasi, Vol. 6(No. 2), 105-118.

Purwaningsih, Y., Istiqomah, N., \& Sutomo, S. (2015). Analisis Dampak Alih Fungsi Lahan terhadap Tingkat Ketahanan Pangan Rumah Tangga Petani di Kabupaten Karanganyar Provinsi Jawa Tengah. AGRARIS: Journal of Agribusiness and Rural Development Research, 1(2), 98-107. https://doi.org/ 10.18196/agr.1213

Rahmadanih, R., Bulkis, S., Amrullah, A., Rukka, R. M., \& Arsyad, M. (2015). Strengthening Institutional Model of Women-Farmers Group in Developing Household Food Diversification. International Journal of Agriculture System, 3(1), 29-40.
Szabo, S. (2016). Urbanisation and food insecurity risks: Assessing the role of human development. Oxford Development Studies, 44(1), 28-48. https://doi.org/10.1080/ 13600818.2015. 1067292

Veno, A., \& Syamsudin. (2016). Analisis trend kinerja keuangan perbankan syariah tahun 2015 sampai dengan 2017. Jurnal Bisnis Dan Manajemen Islam, 4(1), 21-34.

Wicaksono, H., Putra, E. T. S., \& Muhartini, S. (2015). Kesesuaian tanaman ganyong (Canna indica L.), suweg (Amorphophallus paeoniifolius (Dennst.) Nicolson), dan ubi kayu (Manihot esculenta Crants) pada agroforestri Perbukitan Menoreh. Vegetalika, 4(1), 87-101. https://doi.org/10.1016/j.ssci. 2006.08.029

Yasar, M., \& Siwar, C. (2016). Paddy Field Conversion in Malaysia: Issues and Challenges. Rona Teknik Pertanian, 9(2), 168-177. 